\title{
Microarray analysis of the Escherichia coli response to CdTe-GSH Quantum Dots: understanding the bacterial toxicity of semiconductor nanoparticles
}

\author{
Juan P Monrás ${ }^{1}$, Bernardo Collao ${ }^{1,6}$, Roberto C Molina-Quiroz ${ }^{2,3}$, Gonzalo A Pradenas ${ }^{1}$, Luis A Saona ${ }^{1,2}$, \\ Vicente Durán-Toro ${ }^{1,2}$, Nicolás Órdenes-Aenishanslins ${ }^{1,2}$, Felipe A Venegas ${ }^{1}$, David E Loyola ${ }^{3}$, Denisse Bravo ${ }^{4}$, \\ Paulina F Calderón ${ }^{5}$, Iván L Calderón ${ }^{5}$, Claudio C Vásquez ${ }^{3}$, Thomas G Chasteen ${ }^{7}$, Desiré A Lopez ${ }^{7}$ \\ and José M Pérez-Donoso ${ }^{1,8^{*}}$
}

\begin{abstract}
Background: Most semiconductor nanoparticles used in biomedical applications are made of heavy metals and involve synthetic methods that require organic solvents and high temperatures. This issue makes the development of water-soluble nanoparticles with lower toxicity a major topic of interest. In a previous work our group described a biomimetic method for the aqueous synthesis of CdTe-GSH Quantum Dots (QDs) using biomolecules present in cells as reducing and stabilizing agents. This protocol produces nanoparticles with good fluorescent properties and less toxicity than those synthesized by regular chemical methods. Nevertheless, biomimetic CdTe-GSH nanoparticles still display some toxicity, so it is important to know in detail the effects of these semiconductor nanoparticles on cells, their levels of toxicity and the strategies that cells develop to overcome it.

Results: In this work, the response of E. coli exposed to different sized-CdTe-GSH QDs synthesized by a biomimetic protocol was evaluated through transcriptomic, biochemical, microbiological and genetic approaches. It was determined that: i) red QDs (5 $\mathrm{nm}$ ) display higher toxicity than green $(3 \mathrm{~nm})$, ii) QDs mainly induce expression of genes involved with $\mathrm{Cd}^{+2}$ stress (zntA and znuA) and tellurium does not contribute significantly to QDs-mediated toxicity since cells incorporate low levels of Te, iii) red QDs also induce genes related to oxidative stress response and membrane proteins, iv) $\mathrm{Cd}^{2+}$ release is higher in red QDs, and v) QDs render the cells more sensitive to polymyxin B.

Conclusion: Based on the results obtained in this work, a general model of CdTe-GSH QDs toxicity in E. coli is proposed. Results indicate that bacterial toxicity of QDs is mainly associated with cadmium release, oxidative stress and loss of membrane integrity. The higher toxicity of red QDs is most probably due to higher cadmium content and release from the nanoparticle as compared to green QDs. Moreover, QDs-treated cells become more sensitive to polymyxin B making these biomimetic QDs candidates for adjuvant therapies against bacterial infections.
\end{abstract}

Keywords: Toxicity mechanism, Transcriptomic response, Oxidative stress, Cadmium, Nanoparticles

\footnotetext{
* Correspondence: jose.perez@unab.cl

${ }^{1}$ Bionanotechnology and Microbiology Lab, Center for Bioinformatics and

Integrative Biology (CBIB), Universidad Andres Bello, Santiago, Chile

${ }^{8}$ Centro Interdisciplinario de Neurociencia de Valparaíso, Facultad de

Ciencias, Universidad de Valparaíso, Valparaíso, Chile

Full list of author information is available at the end of the article
} 


\section{Background}

Quantum dots (QDs) are fluorescent semiconductor nanoparticles composed of a metallic core and a surface layer of organic and/or inorganic molecules [1,2]. The metallic core determines the novel properties of QDs (spectroscopic, catalytic, etc.) and the surface layer modulates their toxicity and solvent stability $[3,4]$. One of the most intrinsic properties of QDs is their size-dependent emission, a mechanical quantum effect controlled by the nanoparticle size. As the nanocrystal grows, its fluorescence emission peak can change from shorter wavelengths in small nanoparticles (blue or green emission), to longer wavelengths for bigger nanoparticles (yellow or red). These unique properties allow them to be used in nanoelectronics and biomedical research [5,6]. Cadmium telluride QDs have several properties such as broad light absorption, narrow emission and photostability, which make them an interesting material for medical treatments in photodynamic therapy when conjugated with photosensitizers and targeting probes, molecular imaging and therapeutic targeting, among other applications in nanomedicine [7-9].
Most QDs described so far exhibit some toxicity; however, many studies have proven that using thiols as stabilizing ligands decrease their toxic effects [10-12]. Thiols also render QDs water-soluble thus favoring their conjugation with antibodies, nucleic acids and proteins, increasing their applications $[13,14]$. Based on their bacterial toxicity, CdTe and other nanoparticles (iron, silver and gold) have been tested as antibacterial agents, alone or conjugated with antibiotics [15-18].

Given the wide range of applications that QDs display, it is of major importance to determine the effects that these nanoparticles have in eukaryotic and prokaryotic organisms. To date, several studies regarding QDs toxicity in different cell lines have been published [19-21], but just a few of them have focused on bacterial toxicity. In these reports, cadmium QDs display different degrees of toxicity, causing a variety of cellular damages at concentrations ranging from $1 \mathrm{nM}$ to $3 \mu \mathrm{M}$ (Table 1). The available evidence reported to date regarding cadmium-QDs toxicity reveals that the effects on bacterial cells are mostly related to membrane damage and reactive oxygen species (ROS)

Table 1 Overview of Cd-QDs toxicity on bacteria

\begin{tabular}{|c|c|c|c|c|c|}
\hline QD & Capping layer & Microorganism & Reported cellular effect & $\begin{array}{l}\text { Concentration } \\
\text { tested }\end{array}$ & Reference \\
\hline cdSe & Carboxyl coated & $\begin{array}{l}\text { E. coli, Bacillus subtilis, } \\
\text { P. aeruginosa }\end{array}$ & Growth inhibition & $80 \mathrm{nM}$ & {$[26]$} \\
\hline CdTe & Cystine & E. coli & $\begin{array}{l}\text { Growth inhibition and ROS } \\
\text { generation }\end{array}$ & $10-40 \mathrm{nM}$ & {$[27]$} \\
\hline CdTe & 3-mercaptopropionic acid & $\begin{array}{l}\text { E. coli, P. aeruginosa, Bacillus } \\
\text { subtilis, Staphylococcus aureus }\end{array}$ & $\begin{array}{l}\text { Membrane damage and ROS } \\
\text { generation }\end{array}$ & $200-300 \mathrm{nM}$ & {$[28]$} \\
\hline CdTe & Thioglycolic acid, glutathione & $\begin{array}{l}\text { Cupriavidus metallidurans, E. coli, } \\
\text { Shewanella oneidensis, B. subtilis }\end{array}$ & $\begin{array}{l}\text { Growth inhibition and bacterial } \\
\text { filamentation }\end{array}$ & $1-100 \mathrm{nM}$ & {$[29]$} \\
\hline CdSe and CdTe & Cysteine and mercaptoacetic acid & Photobacterium phosphoreum & Affects luminescence metabolism & $0,1-800 \mu \mathrm{g} / \mathrm{mL}$ & {$[30]$} \\
\hline CdTe & Cysteine & $\begin{array}{l}\text { E. coli, } P \text {. aeruginosa, B. subtilis, } \\
\text { S. aureus }\end{array}$ & Affects electron transfer & 40-100 nM & {$[31]$} \\
\hline CdTe & Mercaptoacetic acid & E. coli & Membrane damage & 50- $1000 \mathrm{nM}$ & {$[32]$} \\
\hline CdTe & Thioglycolic acid & E. coli & $\begin{array}{l}\text { Reduces viability and ROS } \\
\text { generation }\end{array}$ & $120 \mu \mathrm{g} / \mathrm{mL}$ & {$[33]$} \\
\hline CdTe & 3-mercaptopropionic acid & E. coli & ROS generation & $1 \mathrm{mM}$ & {$[15]$} \\
\hline $\mathrm{CdSe} / \mathrm{CdZnS}$ & $\begin{array}{l}\text { Carboxyl, Polyanionicpolymaleic } \\
\text { anhydride-alt-1-octadecene and } \\
\text { polycationicpolyethylenimine }\end{array}$ & Pseudomonas stutzeri & $\begin{array}{l}\text { Affects denitrification process } \\
\text { and ROS generation }\end{array}$ & $10-500 \mathrm{nM}$ & {$[34]$} \\
\hline CdSe & Octadecylamine & E. coli & No toxicity & $0.01-100 \mu \mathrm{g} / \mathrm{mL}$ & {$[35]$} \\
\hline $\mathrm{CdSe} / \mathrm{ZnS}$ & Carboxyl coated and uncoated & P. aeruginosa & $\begin{array}{l}\text { Oxidative stress and expression } \\
\text { of cadmium efflux systems }\end{array}$ & $20-60 \mathrm{nM}$ & {$[20]$} \\
\hline CdTe & 3-mercaptopropionic acid & E. coli & $\begin{array}{l}\text { Growth inhibition, membrane } \\
\text { damage and cadmium release } \\
\text { from QDs }\end{array}$ & $20-120 \mathrm{nM}$ & {$[23]$} \\
\hline CdTe & $\begin{array}{l}\text { 3-mercaptopropionic acid, } \\
\text { glutathione, } \mathrm{N} \text {-acetyl cysteine }\end{array}$ & E. coli & $\begin{array}{l}\text { Growth inhibition and membrane } \\
\text { damage }\end{array}$ & 100-3 000 nM & {$[36]$} \\
\hline $\mathrm{CdSe} / \mathrm{CdS}$ & Mercaptosuccinic acid & E. coli & $\begin{array}{l}\text { Oxidative stress and cadmium } \\
\text { release from QDs }\end{array}$ & $5-2000 \mathrm{nM}^{*}$ & {$[37]$} \\
\hline
\end{tabular}


generation, and just a few reports have suggested the importance of $\mathrm{Cd}^{2+}$ ions (Table 1). Furthermore, only a few studies have compared cytotoxicity of QDs with the same core but different size, indicating that smaller QDs display higher toxicity than larger nanoparticles. It has been reported that the size of CdTe QDs, contributes to the cellular toxicity of nanoparticles, with smaller QDs exhibiting more toxicity than larger nanoparticles [22]. The same effect was seen in different sized CdTe and CdSe QDs, where smaller nanoparticles exerted the highest toxicity in E. coli cells and other cell lines [23,24]. On the other hand, in 2011 Yang et al. analyzed the transcriptional response of Pseudomonas stutzeri exposed to chemically-synthesized QDs and observed changes in the transcription profile of 7 genes including some denitrification genes (narG, napB, nirH and nor $B$ ) and the up-regulation of the superoxide dismutase gene $(\operatorname{sod} B)$, suggesting the production of ROS [25]. Also, analyses, made by the same group on $P$. aeruginosa PAO1 exposed to CdSe QDs, determined the expression of a few selected genes related to heavy metals and oxidative stress response [20]. Despite all these antecedents, no global transcriptional analysis of bacteria exposed to QDs has been reported to date.

Recently, our group developed a biomimetic method to synthesize GSH-coated CdTe QDs (CdTe-GSH). QDs synthesized by this method display high biocompatibility and stable fluorescence varying from green to red emission as the size of the NPs grows (3 to $5 \mathrm{~nm}$, respectively) [38-40]. Even though these QDs present low toxicity, they generate some degree of necrosis in cell lines [39] and inhibit bacterial growth [38]. Conversely to most nanoparticles reported to date [22-24], small size green biomimetic QDs display lower toxicity than red QDs as a consequence of a lower cadmium content and higher amount of GSH in the external layer [38,39].

In this work, the $E$. coli global transcriptional response to green and red CdTe-GSH QDs was determined. Genetic, biochemical and microbiological experimental approaches were used to validate microarray results and to shed light on QDs toxicity in E. coli. Based on these results a toxicity mechanism was proposed and the use of QDs as antibiotic adjuvants was evaluated.

\section{Results and discussion}

\section{Microarray analysis of QDs-treated cells}

To evaluate the toxicity of green and red CdTe-GSH QDs in E. coli, MICs (minimal inhibitory concentrations) in the presence of these QDs were determined. E. coli MICs of green and red QDs are 2000 and $125 \mu \mathrm{g} / \mathrm{mL}$, respectively, confirming that these CdTe-GSH QDs display differential toxicity against $E$. coli, with red QDs clearly more toxic than green nanoparticles.

To understand the bacterial global response to QDs of different size, gene expression changes in $E$. coli were determined by microarray analysis after 15 min exposure to $50 \mu \mathrm{g} / \mathrm{mL}$ red or green QDs. This concentration was selected based on previous results indicating that growth of $E$. coli cultures amended with $50 \mu \mathrm{g} / \mathrm{mL}$ red or green biomimetic QDs in exponential phase was not affected [38].

An E. coli transcriptomic analysis of 4619 open reading frames - after QDs exposure - indicated the induction or repression of several genes (Additional file 1: Tables S3 and Additional file 2: Table S4). Microarray data were validated by comparing the expression ratio of 14 genes (adhE, clpB, dnaK, hfq, kpdE, marR, minD, $n f r B, \operatorname{omp} W$, soxS, $\operatorname{tr} x C, w z x E, z n t A$ and $z n u A)$ with the results of expression determined by real-time PCR (Additional file 3: Figure S1). Microarray results showed that 95 and 42 genes are regulated in response to red and green QDs, respectively (Figure 1A). Thus, 2.6\% of the genome is modulated by red QDs while only $0.9 \%$ is regulated under green QDs treatment (Figure 1A). Furthermore, 7 genes were regulated by both treatments (Figure 1A, Additional file 4: Table S5). Gene Ontology (GO) analysis indicated that the most affected processes in exposure to green or red QDs are related to transport, biosynthesis and metabolism (Figure $1 \mathrm{~B}$ and $\mathrm{C}$ ). However, in the case of red QDs treatment, a high modulation in genes related to transport (almost 4-fold higher than that observed with green QDs) and a moderate effect on genes involved in glycolysis and tricarboxylic acid cycle were observed (Figure 1C).

Several QDs-modulated genes determined in this transcriptomic analysis were previously reported in $\mathrm{Cd}^{2+}$-exposed $E$. coli through microarray experiments $(\operatorname{trx} C$, soxS, zntA, adhE, dnaK, hfq, clpB, marR, sucA, $\operatorname{csp} A$ and $\operatorname{csp} B$ ), confirming the relevance of $\mathrm{Cd}^{2+}$ release in biomimetic QDs toxicity [41]. Moreover, a subset of genes modulated by these QDs and not previously associated with $\mathrm{Cd}^{2+}$ transcriptional response was determined $(y b g K, c l p S, h y l C, y f c F, n r f C, f t n, f e o B$, $n i k A D$, ompF, omp $W$, among others). Transcriptional modulation of these genes may reflect the existence of a different and still unreported $\mathrm{Cd}$-independent toxicity mechanism of CdTe-GSH QDs.

Red QDs induce the transcription of a large set of genes related to oxidative stress. Also, an increased level of transcripts related with protein re-assembly, degradation and disaggregation [41-44] was determined in cells exposed to QDs: $c l p S, c p l B$ and $d n a K$ induced by red and hycl by green QDs. Protein degradation could be a result of oxidative damage caused by treatment with QDs. This idea is supported by the increased transcription of $\operatorname{tr} x C$, encoding the oxidative defense-related thioredoxin 2 ( $\operatorname{Tr} x 2)$ [45], in cells exposed to red QDs. Trx2 is involved in the thiol redox homeostasis and its augmented expression has been related to $\mathrm{Cd}^{2+}$ exposure 


\section{A) Total genes regulated $>2$-fold}

\begin{tabular}{cccccc} 
& & Up regulated & Down regulated & Total & \% of genome* \\
\cline { 2 - 6 } Green CdTe-GSH QDs & 16 & 26 & 42 & 0.91 & 7 \\
Red CdTe-GSH QDs & 43 & 52 & 95 & 2.6 & $7{ }^{\dagger}$
\end{tabular}

B)

\section{Green QDs}

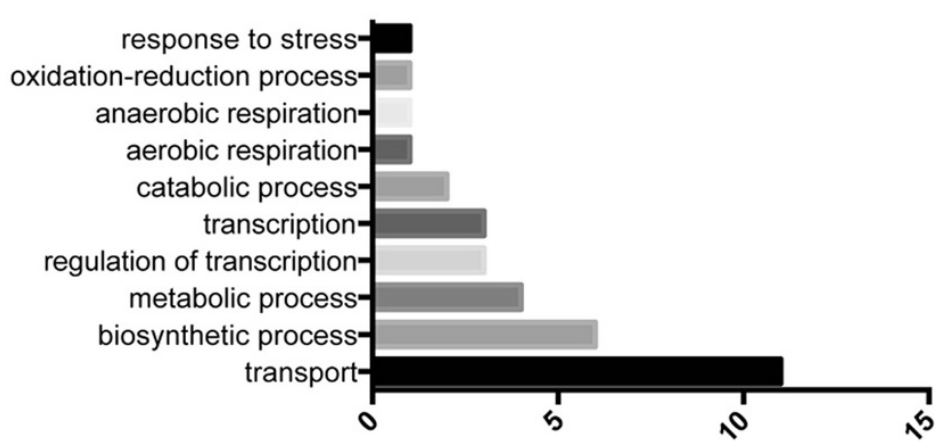

Number of regulated genes

C)

Red QDs

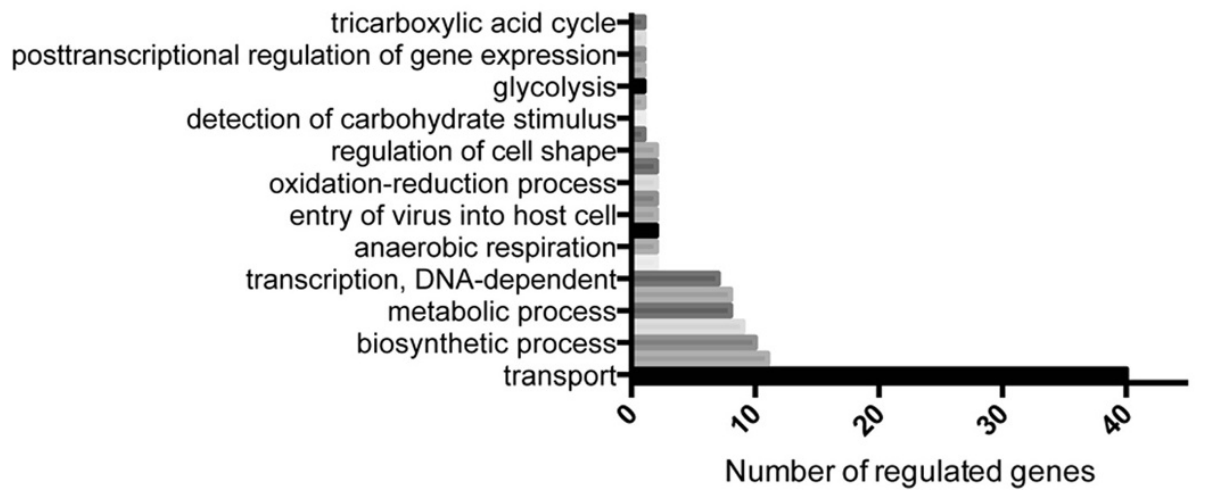

Figure 1 Gene regulation in E. coli exposed to green or red QDs. (A) Summary of total genes regulated in response to green, red and both QDs. Bar charts showing the number of regulated genes sharing specific Gene Ontology (GO) terms after red (B) and green QDs (C) treatment. *Whole genome reference set containing 4619 E. coli genes. tGenes found in both treatments.

and oxidative stress $[46,47]$. The induction of SoxS, a transcriptional factor activated by the oxidative stress response regulator SoxR, was also observed in cells exposed to biomimetic QDs. This factor regulates the transcription of several genes involved in the defense against oxidative stress, such as $\operatorname{sod} A$ (superoxide dismutase), and modulates other cellular processes, like membrane permeability, by regulating the expression of efflux systems (e.g. AcrATolC) and outer membrane proteins (e.g. ompF) [48].

Other evidences of oxidative damage-observed exclusively in red QDs-comes from the increased expression of genes related (directly or indirectly) to oxidative stress response (Additional file 1: Tables S3 and Additional file 2: Table S4). Among them are: $a d h E$, encoding for alcohol dehydrogenase $\mathrm{E}$ which has been associated with resistance to protein oxidation [49]; $h f q$, which is involved in post-transcriptional regulation of oxidative and envelope stress response [50,51]; and $\operatorname{mar} R$, a transcriptional regulator of genes involved in the defense against oxidative stress and several other stresses [52]. All these genes have been previously determined as part of the cadmium regulon response [41]. Newly described genes 
responding to QDs exposure such as $y f c F$, whose product has glutathione peroxidase activity [53], and $l y s U$, encoding an oxidative stress related alarmone [54], could be part of a novel CdTe-GSH QDs response.

A source of ROS generation is free $\mathrm{Fe}^{2+}$ that can produce hydroxyl radical through the Fenton reaction inside the cell [55]. To avoid this $\mathrm{Fe}^{2+}$-dependent Fenton reaction after red QDs exposure, E. coli decreases paaD and $n r f C$ expression, leading to reduced intracellular levels of iron-sulfur clusters [56,57]; it also induces ftn transcription, which would reduce available iron in the cytoplasm [58]. In exposure to green QDs, there is a repression of the $f e o B$ iron transporter, thus shutting down the entrance of iron into the cell cytoplasm. All these results may reflect $E$. coli's strategies to defend itself against CdTe-GSH QD-generated oxidative damage, a result that is in agreement with previous reports on Cd-based NPs [15,23,27,28,32-34,36,37].

Another effect observed after E. coli exposure to red QDs was related to sugar and amino acid metabolism. The expression of genes related to several metabolic pathways seems to be modulated, favoring the accumulation of antioxidant metabolites such as pyruvate (e.g. sdaA, favoring the serine deamination to pyruvate and ammonia; and $a l a C$, deaminating alanine to glutamate and pyruvate). Increased pyruvate content may be related to a metabolic reconfiguration since this metabolite is a known ROS scavenging agent [59]. Moreover, lower sucA expression may favor the accumulation of 2-oxoglutarate, which is also associated with oxidative stress protection [60]. These results suggest a concerted metabolic response to increase protection against oxidative damage.

QDs stress responses associated with metal transporters were observed in E. coli exposed to both green and red nanoparticles. For instance, higher $z h t A$ (a metal efflux pump) [61] and $z n u A$ (an influx pump of zinc) [62] transcript levels were observed upon QDs exposure. ZnuA, a periplasmic zinc-binding protein that allows the influx of $\mathrm{Zn}^{2+}$, has been described as a membrane and macromolecules stabilizer [63,64], and also as antioxidant [65]. On the other hand, down regulation of nikAD in response to CdTe-GSH QDs could be explained by the possibility of this nickel transporter allowing the influx of $\mathrm{Cd}^{2+}$ and/or other pro-oxidant metals.

When QDs come into close contact with the bacterial cell, the first interaction should be with the cell envelope, a multilayered complex structure that serves as the first line of defense against many environmental stresses. It has been reported that GSH-coated QDs have a greater effect on membrane function than other thiolcoated QDs, probably due to GSH lipophilicity [36]. In this context, nanoparticle damage to the bacterial membrane and $\mathrm{Cd}$-induced stress could act in conjunction to affect membrane function, thus explaining why this envelope stress response has not been determined by other $\mathrm{Cd}$ microarray studies $[41,66]$. Some secondary transporters are suppressed suggesting membrane damage or a mechanism preventing metal entrance. Among them, lamb and $l l d P$ encoding a lactate permease; malF, malM and malE coding maltose uptake systems; and his $Q$, involved in histidine, lysine and arginine uptake. Also, a number of transporters involved in the entry of oxidant species such as ompF and omp $W$, among others, are down-regulated in QDs-exposed cells [67]. The downregulation of the major porin OmpF during red QDs treatment reveals that there is a major shut down of the entry of several molecules to the cell. This kind of effect has been reported to be a posttranscriptional repression, mediated by micF, an antisense RNA regulated positively by activation of the SoxRS regulon, in response to redox stress [48]. On the other hand, green QDs down-regulate the expression of OmpW, an outer membrane protein that allows the incorporation of oxidants such as $\mathrm{H}_{2} \mathrm{O}_{2}$ and $\mathrm{NaOCl}$; accordingly it is well known that OmpW is down-regulated when the cell faces oxidative stress [67].

In general, microarray results indicated that QDs exposure modulates the expression of genes involved in membrane and oxidative stress defense, metal transport and metabolic processes (Figure $2 \mathrm{~A}$ and $\mathrm{B}$, Additional file 1: Tables S3 and Additional file 2: Table S4).

\section{ROS generation and membrane damage}

Based on microarray results we decided to evaluate the generation of ROS and membrane damage in E. coli cells exposed to biomimetic QDs. The fluorescent probes $\mathrm{H}_{2}$ DCFDA and PI were used in flow cytometry experiments to detect ROS and membrane damage, respectively. Only red QDs increased ROS production and membrane damage at $50 \mu \mathrm{g} / \mathrm{mL}$, while green QDs do not produce any effect at the same concentration (Figure 3 ) or even at $500 \mu \mathrm{g} / \mathrm{mL}$ (data not shown). Obtained results are in agreement with the transcriptional response determined for red and green biomimetic QDs, and confirm that these QDs produce differential effect in cells mostly related to oxidative damage.

\section{In vivo and in vitro release of metal}

Based on microarray results, and to evaluate if QDs toxicity is related to metal release, ICP-AES analysis of intracellular $\mathrm{Te}$ and $\mathrm{Cd}$ was carried out in cells previously exposed to $50 \mu \mathrm{g} / \mathrm{mL}$ QDs. After $2 \mathrm{~h}$ treatment, cells exposed to green or red QDs accumulated similar amounts of Te $(1.46 \pm 0.02$ and $1.38 \pm 0.03 \mu \mathrm{g} / \mathrm{mL}$, respectively) (Figure 3). In addition, similar uptake kinetics were observed in cells exposed to both kinds of QDs, reaching maximal incorporation after 15 min exposure (Figure 3). These results suggest that $\mathrm{Te}$ is not related to 

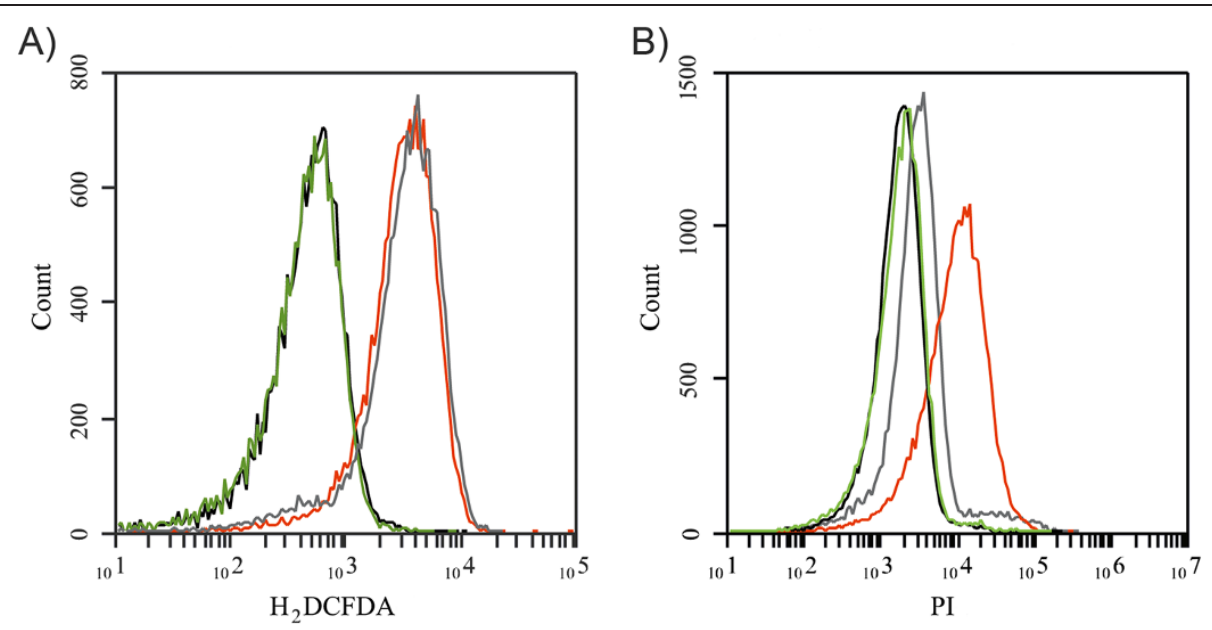

Figure 2 QDs-mediated ROS production and membrane damage in E. coli. (A) H2DCFDA-FACS histogram for ROS detection and (B) PI-FACS histogram for membrane damage detection. Cells were treated with green (green line) or red (red line) QDs during 30 min. Black and grey lines represent non-treated cells and cells exposed to $50 \mathrm{mM} \mathrm{H} 2 \mathrm{O} 2$ (positive control), respectively. Results shown are representative of three independent experiments.

the differential effect observed between exposure to green and red QDs and supports the idea that Te is not the main element responsible of CdTe-GSH QDs toxicity in E. coli. Cd accumulation increased over time in cells exposed to green or red QDs; however, a higher uptake was observed in cells exposed to red QDs (Figure 3). After $2 \mathrm{~h}, \mathrm{Cd}$ accumulation reached $6.4 \pm 0.29$ and $4.23 \pm 0.25 \mu \mathrm{g} / \mathrm{mL}$ for red and green QDs, respectively (Figure 3). Intracellular Cd content was always higher in cells exposed to red QDs, a result that is in agreement with the increased $\mathrm{Cd}$ content previously determined in this nanoparticle [39].

Next, experiments were carried out to evaluate if $\mathrm{Cd}$ release is an intrinsic property of Cd-containing QDs or is a consequence of their interaction with bacterial cells. $\mathrm{Cd}$ released by green and red QDs in the absence of cells was determined by FAAS (flame atomic absorption spectrometry). Biomimetic QDs released almost undetectable amounts of metal at $50 \mu \mathrm{g} / \mathrm{mL}$ exposure, so QDs concentrations of $1000 \mu \mathrm{g} / \mathrm{mL}$ were tested. Results indicated that both QDs sizes released Cd in the absence of bacteria; however, red QDs released a statistically significant 2.5-fold more metal than green QDs $(0.17 \pm 0.01$ versus $0.49 \pm 0.04 \mu \mathrm{g} / \mathrm{mL} \mathrm{Cd}^{2+}$, respectively). This result demonstrates that CdTe-GSH QDs release small amounts of $\mathrm{Cd}$ passively into the medium independently of the presence of bacterial cells, with red nanoparticles releasing higher amounts of this toxic element. Interestingly, results suggest that nanoparticle dismantling is favored in the presence of bacterial cells, since $\mathrm{Cd}$ was detected inside bacteria exposed to $50 \mu \mathrm{g} / \mathrm{mL}$ QDs (a concentration in which $\mathrm{Cd}$ release is undetectable in vitro).

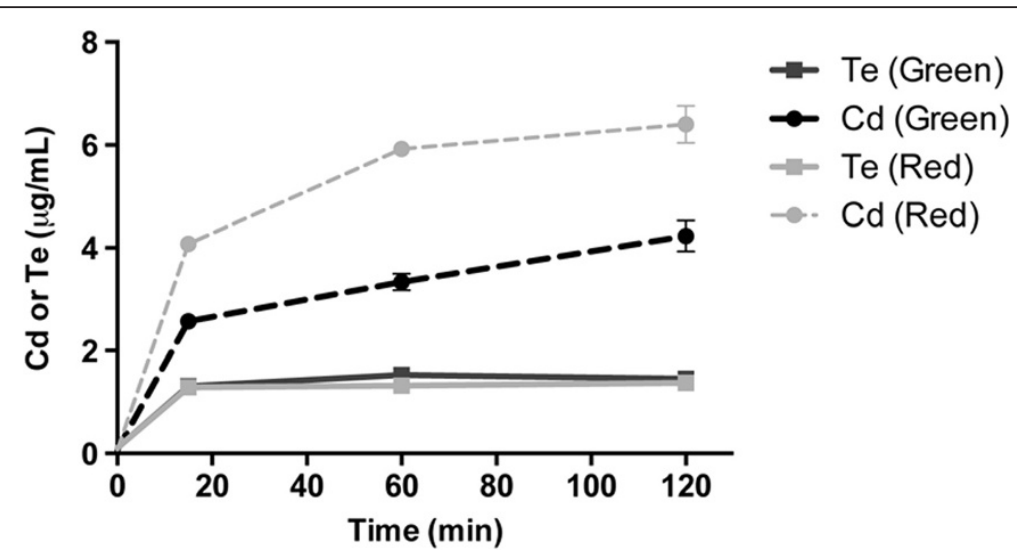

Figure 3 Release of cadmium by green and red QDs. In vivo cadmium uptake kinetics of cells exposed to QDs. Values are mean \pm SD. Experiments were repeated three times and asterisks represent statistical differences between treatments $\left({ }^{* *} p<0.001\right)$. 
In previous work, XPS (X-ray photoelectron spectroscopy) experiments indicated that cadmium species on the surface of green and red biomimetic QDs are $\mathrm{CdO} 2$ and $\mathrm{CdO}$, respectively [40]. In addition, since red QDs release higher levels of cadmium (Figure 3) and display low levels of GSH, it is unlikely that Cd-GSH complexes could dissociate from the NP as has been reported for CdSe-GSH QDs [37]. In this context, QDs toxicity most probably depends on the release of $\mathrm{Cd} 2+$ or cadmium oxides, as has been reported for other CdTe QDs [29]. Taken together, the results described here could explain part of the CdTe-GSH toxicity and the differential effect observed between red and green QDs.

\section{QDs toxicity for mutant $E$. coli strains}

Microarray analysis and metal release experiments suggests that CdTe-GSH QDs toxicity is mainly a consequence of $\mathrm{Cd}$ release and oxidative stress. To confirm this hypothesis, the viability of E. coli wild type and mutant strains on genes involved in $\mathrm{Cd}$ response $(\Delta z n t A)$ or oxidative stress defenses $(\Delta \operatorname{tr} x C$ and $\Delta s o x S)$ was assessed after exposure to QDs. All tested genes were positively regulated under QDs stress in the microarray study (Additional file 1: Tables S3 and Additional file 2: Table S4). At exposure levels of $50 \mu \mathrm{g} / \mathrm{mL}$ green QDs, cell viability was insignificantly affected in all strains (Figure 4A); however, viability was significantly affected with red QDs at this concentration. This effect was stronger in $\Delta z n t A$ cells, which lack a gene involved in Cd export $(57.7 \%$ decrease in viability as compared to untreated cells, Figure 4A) [41]. Surprisingly, susceptibility of $\Delta$ soxS and $\triangle \operatorname{trx} C$ strains to QDs was similar to that exhibited by the wild type strain, suggesting that cells probably have other QDs response systems that can deal with oxidative damage when either of those genes is not present. These results indicate that QDs mainly affect the viability of cells lacking $\mathrm{Cd}$ response systems, confirming that $\mathrm{Cd} 2+$ stress is important in CdTe-GSH QDs toxicity.

\section{Effect of antibiotics on QDs-treated cells}

Given that the microarray results indicated that one of the sources of CdTe-GSH QDs toxicity in E. coli is

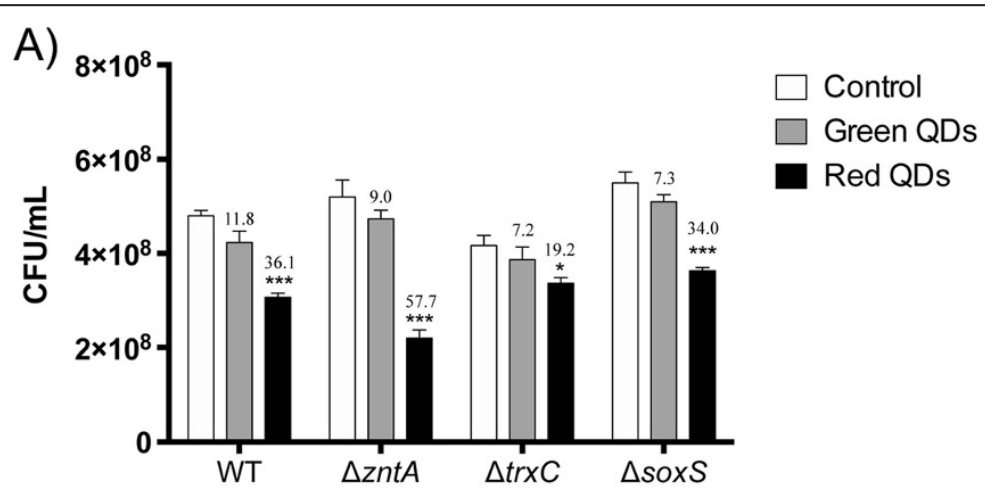

B)

\begin{tabular}{|c|c|c|c|}
\hline & Tetracycline $(\mu \mathrm{g} / \mathrm{mL})$ & Polymyxin $(\mu \mathrm{g} / \mathrm{mL})$ & \multirow{3}{*}{ Untreated } \\
\hline WT & 1.25 & 1.25 & \\
\hline$\Delta z n t A$ & 1.25 & 1.25 & \\
\hline WT & 1.25 & 0.6 & \multirow{2}{*}{ Green QDs } \\
\hline$\Delta z n t A$ & 1.25 & 0.6 & \\
\hline WT & 1.25 & 0.6 & \multirow{2}{*}{ Red QDs } \\
\hline$\Delta z n t A$ & 1.25 & 0.3 & \\
\hline WT & 1.25 & 1.25 & \multirow{2}{*}{$\mathrm{Cd}^{2+} 5 \mu \mathrm{g} / \mathrm{mL}$} \\
\hline$\Delta z n t A$ & 1.25 & 1.25 & \\
\hline WT & 1.25 & 1.25 & \multirow{2}{*}{$\mathrm{Cd}^{2+} 50 \mu \mathrm{g} / \mathrm{mL}$} \\
\hline$\Delta z n t A$ & 1.25 & 1.25 & \\
\hline
\end{tabular}

Figure 4 Effect of QDs on viability and antibiotic susceptibility of E. coli wt and mutant strains. (A) CFUs of E. coli wt, $\triangle Z n t A, \triangle t r x C$ and $\triangle$ soxS strains after $30 \mathrm{~min}$ exposure to green or red QDs. Numbers indicate the viability decrease percentage between control and QDs-treated cells. Values are mean \pm SD. Experiments were repeated three times and asterisks represent statistical differences between control and treatments $\left({ }^{*} \mathrm{p}<0.05,{ }^{* * *} \mathrm{p}<0.001\right)$. (B) MICs to tetracycline and polymyxin B for E. coli wt and $\triangle$ zntA strains pre-treated 15 min with cadmium, green or red QDs (for details see Methods). 
oxidative stress and membrane damage, the antibiotic susceptibility in bacteria previously exposed to green or red QDs was evaluated. Polymyxin B, a ROS generating antibiotic affecting cell membrane, and tetracycline, a bacteriostatic inhibitor of protein synthesis were used. A $\mathrm{MIC}$ of $1.25 \mu \mathrm{g} / \mathrm{mL}$ was determined for tetracycline and polymyxin B for untreated $E$. coli wt and $\Delta z n t A$ strains (Figure 4B). No effect of QDs pre-treatment for the tetracycline MIC was observed. However, when cells were pre-treated with green or red QDs, polymyxin B MIC decreased to $0.6 \mu \mathrm{g} / \mathrm{mL}$ in the wild type strain. A higher effect on polymyxin B antimicrobial activity was observed with red QDs only for the $\Delta z n t A$ strain, an outcome that is in agreement with the higher toxicity of red QDs determined in this work. These results confirm that pre-treatment of bacterial cells with QDs render them more susceptible to polymyxin B and that a mutant-lacking defenses against cadmium injuriesbecame even more sensitive to this antibiotic. Based on this, the effect of $\mathrm{Cd}^{2+}$ pre-treatment on E. coli polymyxin B MIC was evaluated. Surprisingly, no enhancement of polymyxin B antimicrobial effect was observed after $\mathrm{Cd}^{2+}$ pre-treatment ( 5 or $50 \mu \mathrm{g} / \mathrm{mL}$ ) on wt and $\Delta z n t A$ strains (Figure $4 \mathrm{~B}$ ). This result strongly suggests that increased polymyxin $B$ toxicity observed after QDs pre-treatment is not a direct consequence of $\mathrm{Cd}$ release.

Recently, Yang et al. [20] reported that the resistance of $P$. aeruginosa PAO1 to antibiotics increased when the cells were pre-treated with $\mathrm{CdSe} / \mathrm{ZnS}$ QDs, due to the activation of response mechanisms before the antibiotic was added. No such effect was observed in biomimetic CdTe-GSH QDs, probably as a consequence of their different composition and the synthetic procedures used for QDs production. In agreement with our results, other studies concluded that the effectiveness of antibiotics like penicillin G, amoxicillin and erythromycin, increase in the presence of metal nanoparticles [16-18]. Our results indicate that the increased polymyxin B toxicity observed in QDs-treated cells is not associated with cadmium release. These results are in agreement with the microarray analysis indicating that QDs toxicity involves other mechanisms of damage, such as envelope and oxidative stress, among others. Based on the low toxicity to eukaryotic cells that CdTe-GSH QDs display, particularly when compared to Cys-CdTe [38], and the enhanced antibacterial effect of QDs and polymyxin B, CdTe-GSH QDs constitute potential candidates to improve the effect of clinical antimicrobials.

\section{Conclusion}

Based on the transcriptomic, biochemical, microbiological and genetic results from this work, a general model of CdTe-GSH QDs toxicity in E. coli is proposed
(Figure 5). When nanoparticles come into close contact with the bacterium an interaction with the cell envelope is established, and QDs generate a membrane stress that result in the modulation of several membrane transporters (eg. ompF, ompW, malF, malM and malE).

On the other hand, green and red QDs release metal ions $\left(\mathrm{Cd}^{2+}\right.$ and $\left.\mathrm{Te}^{2-}\right)$ from the nanoparticle core when interacting with the bacterial cells. Tellurium does not significantly affect cells since it is present in NPs as telluride $\left(\mathrm{Te}^{2-}\right)$, which in aqueous solution is rapidly oxidized to $\mathrm{Te}^{0}$, a more stable, insoluble, and much less toxic form of tellurium [68]. In contrast, cadmium represents an important source of toxicity, since it is released from the nanoparticle as $\mathrm{Cd}^{2+}$ upon cell interaction and can easily enter by a number of divalent metal transporters [69]. Once inside, cadmium affinity for reduced thiol groups results in thiol depletion and the cell undergoes oxidative stress [41]. Intracellular ROS increase can cause several forms of damage, like protein oxidation and the release of $\mathrm{Fe}^{2+}$ from ironsulfur clusters [55].

All these effects generate a transcriptional response in E. coli that is mainly related to cadmium poisoning, oxidative stress and membrane damage. Bacteria promote $\mathrm{Cd}$ exit through ZntA and the entry of antioxidant molecules like $\mathrm{Zn}^{2+}$ (via ZnuA). Moreover, CdTe-GSH QDs seem to elicit a specific response mediated by these QDs (e.g. $y b g K, c l p S$, $h y l C, y f c F$ and $n r f C$, among others), which involves genes that are not modulated during cadmium or oxidative stress. Among these, $y b g K$ is one of the most interesting since it is strongly up-regulated after both green and red QDs treatment and has no known function to date.

Finally, given the interest in developing therapies and diagnostic tools based on QDs, these results are relevant to understanding the interaction of this kind of nanoparticles with bacterial cells. The fact that QDs-treated cells become more sensitive to polymyxin B could lead to the use of CdTe-GSH QDs as adjuvants in antimicrobial therapies. Green nanoparticles could be used in the diagnosis and treatment of bacterial pathogens susceptible to polymyxin B or other antibiotics acting similarly, as they do not display much toxicity while enhancing polymyxin $\mathrm{B}$ antibacterial activity.

\section{Methods}

\section{Bacterial strains and growth media}

E. coli BW25113 and strains from the KEIO mutant collection [70] were used in all experiments (Additional file 5: Table S1). Cells were grown in LB medium at $37^{\circ} \mathrm{C}$ with constant agitation using an overnight culture as preinoculum (1:100 dilution). Cells from the KEIO collection were grown in LB media supplemented with $30 \mu \mathrm{g} / \mathrm{mL}$ kanamycin. 


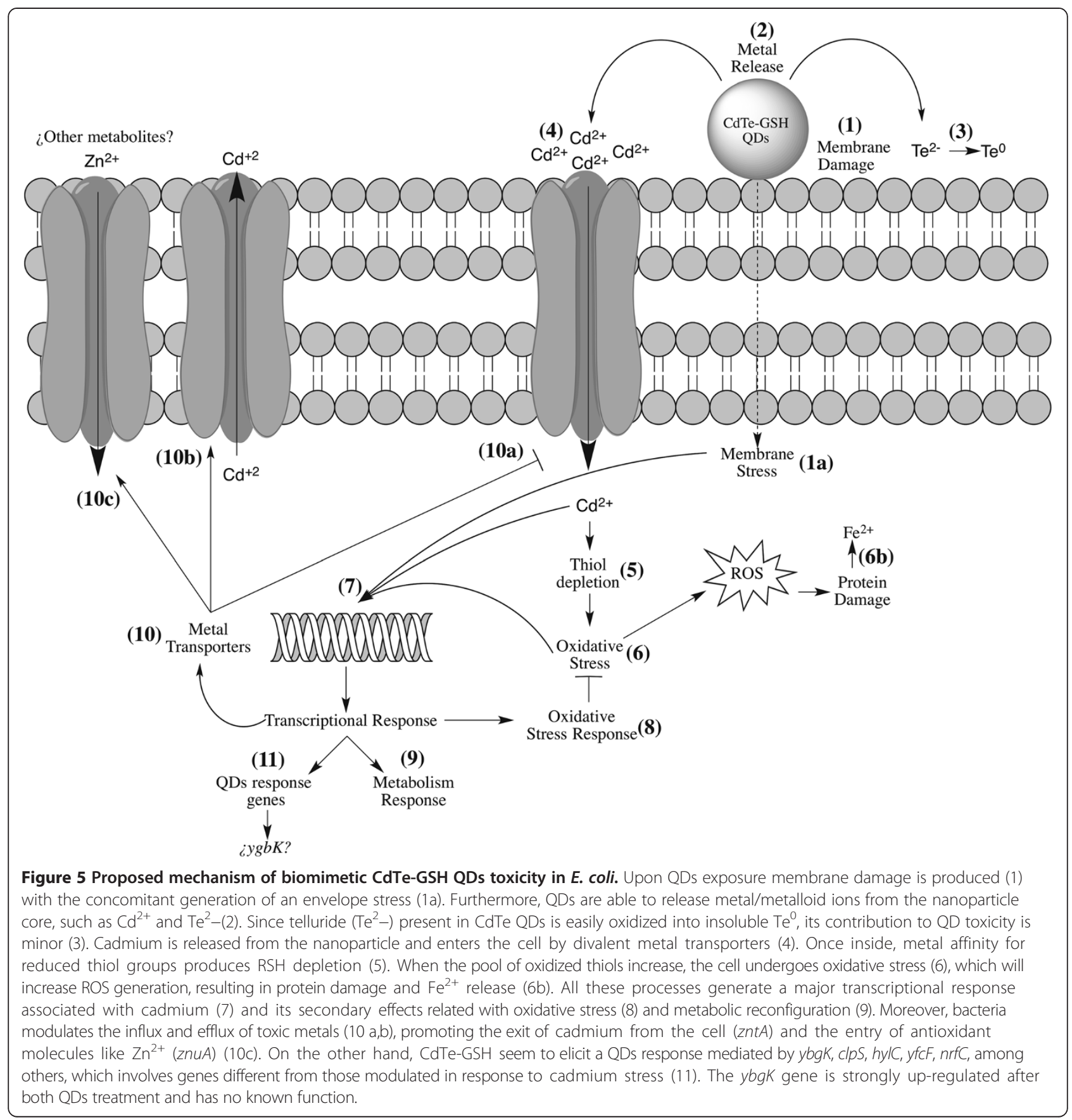

\section{Synthesis of CdTe-GSH QDs}

Green and red QDs were synthesized according to the protocol described by Pérez-Donoso et al. [39]. Briefly, a solution made of cadmium chloride ( $4 \mathrm{mM} \mathrm{CdCl} 2$ ), potassium tellurite $\left(1 \mathrm{mM} \mathrm{K} \mathrm{K}_{2} \mathrm{TeO}_{3}\right)$ and glutathione (15 mM GSH) in $15 \mathrm{mM}$ borax-citrate buffer $\mathrm{pH} 9.4$ was prepared. Afterwards, this solution was incubated in a water bath at $90^{\circ} \mathrm{C}$ and green and red QDs were obtained after 4 and $10 \mathrm{~h}$ incubation, respectively, as the reaction can be stopped at any time simply by incubating on ice or at $4^{\circ} \mathrm{C}$. QDs solutions were dialyzed for $2 \mathrm{~h}$ against borax-citrate buffer $\mathrm{pH} 9.4$ in order to eliminate non bound metal species. Afterwards, CdTe-GSH NPs were precipitated with two volumes of ethanol and centrifuged for $20 \mathrm{~min}$ at $13,000 \times g$. The resulting QDs were dried and weighted to obtain $100 \mathrm{mg} / \mathrm{ml}$ QDs solutions in borax citrate buffer $\mathrm{pH}$ 9.4. CdTe-GSH QDs in aqueous solution prepared by this method are stable and highly fluorescent for months at room temperature, $4^{\circ} \mathrm{C}$ or as powder after alcohol precipitation. 


\section{DNA microarray experiments}

Exponential E. coli cultures $\left(\mathrm{OD}_{600} \sim 0.5\right)$ were exposed for $15 \mathrm{~min}$ to $50 \mu \mathrm{g} / \mathrm{mL}$ red or green QDs and RNA was extracted using the RNeasy Mini kit (Qiagen), following the manufacturer's instructions. The RNA was eluted and subjected to a second round of DNase I (Ambion Turbo DNA-free kit) treatment at $37^{\circ} \mathrm{C}$ for $30 \mathrm{~min}$. RNA concentration and purity was determined using a Nanodrop 2000c spectrophotometer (Thermo).

Labeled cDNA probes were generated by reverse transcription using $20 \mu \mathrm{g}$ of total RNA, SuperScript II (Invitrogen) and Alexa 555 and 647 dyes (Invitrogen). DNA microarrays slides were purchased from Microarrays Inc. and scanned in a ScanArray GX (Perkin Elmer) as described earlier [71]. GenePix Pro v6.0 software was used for image analysis. Limma package implemented in Bioconductor [72] was used to discount the background signal by the normexp method [73] and values were normalized using the LOESS procedure [74]. T-test was used to identify those genes whose change in expression was significant and 3 criteria ( $M$ value, $A$ value and $p$ value from $t$-test) were used for determining differential expression. The threshold for genes to be considered were values of $M \geq 2$ (induction), $\mathrm{M} \leq-2$ (repression); $\mathrm{A} \geq 8$ and $\mathrm{p} \leq 0.05$. All genes that showed differential expression were categorized by Gene Ontology associations (The Gene Ontology Consortium, 2000) using biological process term. By using a custom python script with all Gene Ontology terms, a GO plot based on Ecocyc webpage was constructed and classified [75].

\section{Real time quantitative RT-PCR}

qRT-PCR was performed using the primers listed in Additional file 6: Table S2 as previously described [67], with a minor modification of the PCR program. Briefly, relative quantification was performed using a Brilliant II SYBR Green QPCR Master Reagent Kit and the Mx3000P detection system (Stratagene). 16S rRNA was used for normalization. The reaction mixture was carried out in a final volume of $20 \mu \mathrm{l}$ containing $1 \mu \mathrm{l}$ of diluted cDNA (1:1000), $0.24 \mu \mathrm{l}$ of each primer (120 nM), $10 \mu \mathrm{l}$ of $2 \times$ Master Mix, $0.14 \mu \mathrm{l}$ of diluted $\operatorname{ROX}(1: 200)$ and $8.38 \mu \mathrm{l}$ of $\mathrm{H}_{2} \mathrm{O}$. The reaction was performed under the following conditions: $10 \mathrm{~min}$ at $95^{\circ} \mathrm{C}$ followed by 40 cycles of $30 \mathrm{~s}$ at $95^{\circ} \mathrm{C}, 30 \mathrm{~s}$ at $58^{\circ} \mathrm{C}$ and $30 \mathrm{~s}$ at $72^{\circ} \mathrm{C}$. Finally, a melting cycle from $65^{\circ} \mathrm{C}$ to $95^{\circ} \mathrm{C}$ was performed to check for amplification specificity. Amplification efficiency was calculated from a standard curve constructed by amplifying serial dilutions of RT-PCR products for each gene. These values were used to obtain the fold-change in expression for the gene of interest normalized with $16 \mathrm{~S}$ levels according to Pfaffl [76].

\section{Minimal inhibitory concentrations (MICs)}

MIC determinations were performed in 96 well microplates prepared aseptically adding LB medium and QDs at the desired concentration by serial dilution in a final volume of $150 \mu \mathrm{L}$. E. coli cells were grown to $\mathrm{OD}_{600} \sim 0.5$ and then diluted 10 -fold. Then, $10 \mu \mathrm{L}$ of the diluted cell suspension were added to each well and the plate was incubated at $37^{\circ} \mathrm{C}$ for $24 \mathrm{~h}$. MIC was determined as the concentration where the $\mathrm{OD}_{600}$ was less than or equal to $50 \%$ of the absorbance obtained in the untreated control. Each assay was performed in triplicate.

\section{Flow cytometry assays}

Exponential E. coli cultures $\left(\mathrm{OD}_{600} \sim 0.5\right)$ were exposed for $30 \mathrm{~min}$ to $50 \mu \mathrm{g} / \mathrm{mL}$ red or green QDs or $10 \mathrm{mM}$ $\mathrm{H}_{2} \mathrm{O}_{2}$. Samples were washed with PBS $1 \mathrm{X}$ buffer twice and then were incubated with 2', 7'-dichlorofluorescein diacetate $\left(\mathrm{H}_{2} \mathrm{DCFDA}\right.$, for ROS detection) or propidium iodide (PI, to measure membrane damage) for $10 \mathrm{~min}$. The fluorescence-activated cell sorting (FACS) data was recorded with a BD Biosciences Accuri C6 flow cytometer. $\mathrm{H}_{2}$ DCFDA and PI fluorescence were excited with a $488 \mathrm{~nm}$ argon laser. Emissions were detected with FL1-A (using FL1 emission filter 533/30) and FL3-A (using FL3 emission filter 610/20). Flow cytometry data was analyzed using Kaluza Analysis 1.3.

\section{Metal quantification on QDs-treated cells}

Metal quantification experiments were performed as previously described by Montes et al., [77], with some modifications: $E$. coli was grown at $37^{\circ} \mathrm{C}$ to $\mathrm{OD}_{600} \sim 0.5$ and cultures were amended with $50 \mu \mathrm{g} / \mathrm{mL}$ freshlysynthesized green or red CdTe-GSH QDs. After incubating for 15, 60 or $120 \mathrm{~min}$, cells were sedimented at $10000 \times g$ for $6 \mathrm{~min}$. Supernatants were discarded, pellets were suspended in $1 \mathrm{~mL}$ of $1 \mathrm{~N} \mathrm{HNO}_{3}$ and allowed to dissolve overnight at room temperature. Samples were diluted 1:10 with $1 \mathrm{~N} \mathrm{HNO}_{3}$ and centrifuged at $10000 \times g$ for $6 \mathrm{~min}$. Supernatants were used for cadmium and tellurium quantification by inductively coupled plasma atomic emission spectrometry, ICP-AES (Spectro CIROS Vision ICP-OES) using $1 \mathrm{~N} \mathrm{HNO}_{3}$ as matrix. Calibration curves were constructed using cadmium and tellurium commercially available ICP standards.

\section{in vitro quantification of $\mathrm{Cd}$ released from $\mathrm{QDs}$}

Red and green QDs were diluted to $1000 \mu \mathrm{g} / \mathrm{mL}$ solutions with sterile distilled water. To evaluate cadmium release, QDs solutions were incubated at room temperature for $10 \mathrm{~min}$, mixed with isopropanol (1:1) and centrifuged at $12000 \times g$ for $10 \mathrm{~min}$ to separate the nanoparticles from the soluble cadmium fraction. Supernatants were diluted 1:10 with sterile distilled water and used for metal quantification by flame absorption atomic spectrometry (FAAS) using an AA-260 flame atomic absorption spectrometer (Shimadzu). 


\section{Viability assay}

Viability assays were performed on E. coli wild type and KEIO mutant strains grown to $\mathrm{OD}_{600} \sim 0.5$ and exposed to $50 \mu \mathrm{g} / \mathrm{mL}$ of red or green QDs for $20 \mathrm{~min}$. After treatment, serial dilutions of all strains analyzed were plated on LB agar and colony forming units (CFU) were determined after $24 \mathrm{~h}$.

\section{Antibiotic susceptibility assays}

E. coli was grown in $\mathrm{LB}$ medium at $37^{\circ} \mathrm{C}$ with constant agitation to $\mathrm{OD}_{600} \sim 0.5$. Then, red or green QDs were added to the cultures at a final concentration of $50 \mu \mathrm{g} / \mathrm{mL}$ and incubated for $15 \mathrm{~min}$. In parallel, a $15 \mathrm{~min}$ pretreatment with 5 and $50 \mu \mathrm{g} / \mathrm{mL} \mathrm{CdCl}_{2}$ was performed. After pre-treatments, cells were washed twice with LB medium and used for tetracycline and polymyxin B MIC determination, as described above.

\section{Statistical analysis}

All experiments were performed in three biological and technical replicates. The statistical analyses used the one-way or two-way ANOVA with a post-hoc Bonferroni's test. Differences were considered significant at $\mathrm{p}$ values of $\leq 0.05$ for all statistical analyses.

\section{Availability of supporting data}

The DNA microarray data discussed in this study have been deposited in NCBI Gene Expression Omnibus (GEO; http://www.ncbi.nlm.nih.gov/geo/), and are accessible through GEO series accession no. GSE58912.

http://www.ncbi.nlm.nih.gov/geo/query/acc.cgi?token= qjivcmoyzhqnzcr\&acc=GSE58912.

\section{Additional files}

Additional file 1: TableS3. Genes regulated in response to red QDs. Additional file 2: Table S4. Genes regulated in response to green QDs. Additional file 3: Figure S1. Validation of microarray data using qRT-PCR of randomly selected genes. Total RNA was extracted from wild type strain grown aerobically in LB media until $\mathrm{OD}_{600} \sim 0.5$ and treated with red QDs (A) or green QDs (B) for 15 min to analyze the expression by qRT-PCR. Values are based on fold change (Control/QDs treated) calculated from $\triangle \triangle C$ t values and $\log _{2}$ transformed. All genes present statistically significant differences between control (untreated) and QDs (red or green) treated cells $(p<0.05)$. Data represent the means \pm standard deviations $(n=3)$.

Additional file 4: Table S5. Genes regulated by both red and green QDs. Additional file 5: Table S1. Bacterial strains used in this study.

Additional file 6: Table S2. Primers used in this study.

\section{Abbreviations}

QDs: Quantum Dots; CdTe: Cadmium telluride; GSH: Glutathione; MIC: Minimal inhibitory concentration; ICP-AES: Inductively coupled plasma atomic emission spectrometry; ROS: Reactive oxygen species; LB: Luria Bertani.

\section{Competing interests}

The authors declare that they have no competing interests.

\section{Authors' contributions}

JPM, CCV and JMPD conceived the project. RCMQ and DEL carried out the experimental work for generating and analyzing the microarray data. JPM VDT, BC, RCMQ, FAV, NOA, PFC, ILC and DAL performed the experiments. JPM, GAP, DEL, TGC and JMPD conducted partial data analysis. JPM, BC, GAP, LAS, VDT, NOA, FAV, DB and JMPD wrote the paper. All authors read and approved the final manuscript.

\section{Acknowledgments}

This work was supported by FONDECYT 11110077 (JMP), FONDECYT 11110076 (DB), FONDECYT 1130362 (CV), Anillo ACT 1107 (JMP), Anillo ACT 1111 (JMP, DB), UNAB DI 488-14/R (JMP), and CINV Millennium Initiative 09-022-F (Chile) (JMP). A doctoral fellowship from CONICYT to JPM is also acknowledged. TGC and DAL gratefully acknowledge support from the Robert A. Welch Foundation (X-011).

\section{Author details}

${ }^{1}$ Bionanotechnology and Microbiology Lab, Center for Bioinformatics and Integrative Biology (CBIB), Universidad Andres Bello, Santiago, Chile. ${ }^{2}$ Facultad de Ciencias Químicas y Farmacéuticas, Universidad de Chile, Santiago, Chile. ${ }^{3}$ Facultad de Química y Biología, Universidad de Santiago de Chile, Santiago, Chile. ${ }^{4}$ Facultad de Odontología, Universidad de Chile, Santiago, Chile.

${ }^{5}$ Laboratorio de Microbiología Molecular, Facultad de Ciencias Biológicas, Universidad Andres Bello, Santiago, Chile. ${ }^{6}$ Fraunhofer Chile Research, M. Sánchez Fontecilla 310 piso 14, Santiago, Chile. ${ }^{7}$ Department of Chemistry and Texas Research Institute for Environmental Studies, Sam Houston State University, Huntsville, Texas 77340, USA. ${ }^{8}$ Centro Interdisciplinario de Neurociencia de Valparaíso, Facultad de Ciencias, Universidad de Valparaíso, valparaíso, Chile.

Received: 17 July 2014 Accepted: 26 November 2014

Published: 12 December 2014

\section{References}

1. Talapin DV, Mekis I, Götzinger S, Kornowski A, Benson O, Weller H: CdSe/ $\mathrm{CdS} / \mathrm{ZnS}$ and $\mathrm{CdSe} / \mathrm{ZnSe} / \mathrm{ZnS}$ core-shell-shell nanocrystals. J Phys Chem B 2006, 108:18826-18831.

2. Rogach AL, Franzl T, Klar TA, Feldmann J, Gaponik N, Lesnyak V, Shavel A, Eychmüller A, Rakovich YP, Donegan JF: Aqueous synthesis of thiol-capped CdTe nanocrystals: state-of-the-art. J Phys Chem C 2007, 111:14628-14637.

3. Hoshino A, Fujioka K, Oku T, Suga M, Sasaki YF, Ohta T, Yasuhara M, Suzuki K, Yamamoto K: Physicochemical properties and cellular toxicity of nanocrystal quantum dots depend on their surface modification. Nano Lett 2004, 4:2163-2169

4. Gaponik N, Talapin DV, Rogach AL, Hoppe K, Shevchenko EV, Kornowski A, Eychmüller A, Weller H: Thiol-capping of CdTe nanocrystals: an alternative to organometallic synthetic routes. J Phys Chem Vol B 2002, 106:7177-7185

5. Bimberg D: Quantum dot based nanophotonics and nanoelectronics. Electron Lett 2008, 44:168-171.

6. Medintz IL, Uyeda HT, Goldman ER, Mattoussi H: Quantum dot bioconjugates for imaging, labelling and sensing. Nat Mater 2005, 4:435-446.

7. Zheng Y, Gao S, Ying JY: Synthesis and cell-imaging applications of glutathione-capped CdTe Quantum Dots. Adv Mater 2007, 19:376-380.

8. Rakovich A, Rakovich T, Kelly V, Lesnyak V, Eychmüller A, Rakovich YP, Donegan JF: Photosensitizer methylene blue-semiconductor nanocrystals hybrid system for photodynamic therapy. J Nanosci Nanotechnol 2010, 10:2656-2662.

9. Xue $M$, Wang $X$, Wang $H$, Tang B: The preparation of glutathione-capped CdTe quantum dots and their use in imaging of cells. Talanta 2011, 83:1680-1686.

10. Chen N, He Y, Su Y, Li X, Huang Q, Wang H, Zhang X, Tai R, Fan C: The cytotoxicity of cadmium-based quantum dots. Biomaterials 2012, 33:1238-1244

11. Zhang $H$, Wang $D$, Möhwald $H$ : Ligand-selective aqueous synthesis of one-dimensional CdTe nanostructures. Angew Chem Int Ed 2006, 45:748-751.

12. Silva FO, Carvalho MS, Mendonça R, Macedo WA, Balzuweit K, Reiss P, Schiavon MA: Effect of surface ligands on the optical properties of aqueous soluble CdTe quantum dots. Nanoscale Res Lett 2012, 7:1-10.

13. Kouassi GK, Irudayaraj J: Magnetic and gold-coated magnetic nanoparticles as a DNA sensor. Anal Chem 2006, 78:3234-3241. 
14. Zhang Y, So MK, Loening AM, Yao H, Gambhir SS, Rao J: HaloTag proteinmediated site-specific conjugation of bioluminescent proteins to quantum dots. Angew Chem Int Ed 2006, 45:4936-4940.

15. Park S, Chibli H, Wong J, Nadeau JL: Antimicrobial activity and cellular toxicity of nanoparticle-polymyxin B conjugates. Nanotechnology 2011 22:185101.

16. Shahverdi AR, Fakhimi A, Shahverdi HR, Minaian S: Synthesis and effect of silver nanoparticles on the antibacterial activity of different antibiotics against Staphylococcus aureus and Escherichia coli. Nanomed-Nanotechnol 2007, 3:168-171.

17. Allahverdiyev AM, Kon KV, Abamor ES, Bagirova M, Rafailovich M: Coping with antibiotic resistance: combining nanoparticles with antibiotics and other antimicrobial agents. Expert Rev Anti-Infect Ther 2011, 9:1035-1052.

18. Murugan S, Paulpandian P: Synergistic antibacterial evaluation of commercial antibiotics combined with nanoiron against human pathogens. Int J Pharm Sci Rev Res 2013, 18:183-190.

19. Zhang T, Stilwell JL, Gerion D, Ding L, Elboudwarej O, Cooke PA, Gray JW, Alivisatos AP, Chen FF: Cellular effect of high doses of silica-coated quantum dot profiled with high throughput gene expression analysis and high content cellomics measurements. Nano Lett 2006, 6:800-808.

20. Yang Y, Mathieu JM, Chattopadhyay S, Miller JT, Wu T, Shibata T, Guo W, Alvarez PJ: Defense mechanisms of Pseudomonas aeruginosa PAO1 against quantum dots and their released heavy metals. ACS Nano 2012, 6:6091-6098.

21. Simon DF, Domingos RF, Hauser C, Hutchins CM, Zerges W, Wilkinson K Transcriptome sequencing (RNA-seq) analysis of the effects of metal nanoparticle exposure on the transcriptome of Chlamydomonas reinhardtii. Appl Environ Microbiol 2013, 79:4774-4785.

22. Lovrić J, Bazzi HS, Cuie Y, Fortin GR, Winnik FM, Maysinger D: Differences in subcellular distribution and toxicity of green and red emitting $\mathrm{CdTe}$ quantum dots. J Mol Med 2005, 83:377-385.

23. Fang $T$, Li X, Wang QS, Zhang ZJ, Liu P, Zhang CC: Toxicity evaluation of CdTe quantum dots with different size on Escherichia coli. Toxicol in Vitro 2012, 26:1233-1239.

24. Shiohara A, Hoshino A, Hanaki Kl, Suzuki K, Yamamoto K: On the cytotoxicity caused by Quantum Dots. Microbiol Immunol 2004, 48:669-675.

25. Yang $Y$, Zhu $H$, Colvin VL, Alvarez PJ: Cellular and transcriptional response of Pseudomonas stutzeri to quantum dots under aerobic and denitrifying conditions. Environ Sci Tech 2011, 45(11):4988-4994.

26. Mahendra S, Zhu H, Colvin VL, Alvarez PJ: Quantum dot weathering results in microbial toxicity. Environ Sci Technol 2008, 42:9424-9430.

27. Lu Z, Li CM, Bao H, Qiao Y, Bao Q: Photophysical mechanism for quantum dots-induced bacterial growth inhibition. J Nanosci Nanotechnol 2009, 9:3252-3255.

28. Dumas EM, Ozenne V, Mielke RE, Nadeau JL: Toxicity of CdTe quantum dots in bacterial strains. IEEE T Nanobiosci 2009, 8:58-64

29. Schneider R, Wolpert C, Guilloteau H, Balan L, Lambert J, Merlin C: The exposure of bacteria to CdTe-core quantum dots: the importance of surface chemistry on cytotoxicity. Nanotechnology 2009, 20:225101.

30. Wang L, Zheng H, Long Y, Gao M, Hao J, Du J, Mao X, Zhou D: Rapid determination of the toxicity of quantum dots with luminous bacteria. J Hazard Mater 2010, 177:1134-1137.

31. Dumas E, Gao C, Suffern D, Bradforth SE, Dimitrijevic NM, Nadeau JL: Interfacial charge transfer between CdTe quantum dots and gram negative vs gram positive bacteria. Environ Sci Technol 2010, 44:1464-1470.

32. Wang Q, Fang T, Liu P, Min X, Li X: Study of the bioeffects of CdTe quantum dots on Escherichia coli cells. J Colloid Interf Sci 2011, 363:476-480

33. Luo Z, Wu Q, Zhang M, Li P, Ding Y: Cooperative antimicrobial activity of CdTe quantum dots with rocephin and fluorescence monitoring for Escherichia coli. J Colloid Interf Sci 2011, 362:100-106.

34. Yang Y, Zhu H, Colvin VL, Alvarez PJ: Cellular and transcriptional response of Pseudomonas stutzeri to quantum dots under aerobic and denitrifying conditions. Environ Sci Technol 2011, 45:4988-4994.

35. Pokhrel LR, Silva T, Dubey B, El Badawy AM, Tolaymat TM, Scheuerman PR: Rapid screening of aquatic toxicity of several metal-based nanoparticles using the MetPLATE ${ }^{\mathrm{TM}}$ bioassay. Sci Total Environ 2012, 426:414-422.

36. Lai L, Lin C, Xiao CQ, Xu ZQ, Han XL, Fu L, Li DW, Mei P, Jiang FL, Guo QL, Liu Y: Adhesion of quantum dots-induced membrane damage of Escherichia coli. J Colloid Interf Sci 2013, 389:61-70.
37. Kauffer FA, Merlin C, Balan L, Schneider R: Incidence of the core composition on the stability, the ROS production and the toxicity of CdSe quantum dots. J Hazard Mater 2014, 268:246-255.

38. Díaz V, Ramírez-Maureira M, Monrás JP, Vargas J, Bravo D, Osorio-Román IO, Vásquez CC, Pérez-Donoso JM: Spectroscopic properties and biocompatibility studies of CdTe Quantum Dots capped with biological thiols. Sci Adv Mater 2012, 4:1-8.

39. Pérez-Donoso JM, Monrás JP, Bravo D, Aguirre A, Quest AF, Osorio-Román IO, Aroca RF, Chasteen TG, Vásquez CC: Biomimetic, mild chemical synthesis of CdTe-GSH quantum dots with improved biocompatibility. PloS one 2012, 7:e30741.

40. Gautier JL, Monrás JP, Osorio-Román IO, Vásquez CC, Bravo D, Herranz T, Marco JF, Pérez-Donoso JM: Surface characterization of GSH-CdTe quantum dots. Mater Chem Phys 2013, 140:113-118.

41. Wang A, Crowley DE: Global gene expression responses to cadmium toxicity in Escherichia coli. J Bacteriol 2005, 187:3259-3266.

42. Schmidt R, Zahn R, Bukau B, Mogk A: ClpS is the recognition component for Escherichia coli substrates of the $\mathrm{N}$-end rule degradation pathway. Mol Microbiol 2009, 72:506-517.

43. Doyle SM, Wickner S: Hsp104 and ClpB: protein disaggregating machines. Trends Biochem Sci 2009, 34:40-48.

44. Dougan DA, Mogk A, Bukau B: Protein folding and degradation in bacteria: to degrade or not to degrade? That is the question. Cell Mol Life Sci 2002, 59:1607-1616.

45. Stewart EJ, Aslund F, Beckwith J: Disulfide bond formation in the Escherichia coli cytoplasm: an in vivo role reversal for the thioredoxins. EMBO J 1998, 17:5543-5550.

46. Carmel-Harel O, Storz G: Roles of the glutathione-and thioredoxindependent reduction systems in the Escherichia coli and Saccharomyces cerevisiae responses to oxidative stress. Annu Rev Microbiol 2000 54:439-461

47. Rollin-Genetet F, Berthomieu C, Davin AH, Quemeneur E: Escherichia coli thioredoxin inhibition by cadmium. Eur J Biochem 2004, 271:1299-1309.

48. Chou JH, Greenberg JT, Demple B: Posttranscriptional repression of Escherichia coli OmpF protein in response to redox stress: positive control of the micF antisense RNA by the soxRS locus. J Bacteriol 1993, 175:1026-1031.

49. Echave P, Tamarit J, Cabiscol E, Ros J: Novel antioxidant role of alcohol dehydrogenase E from Escherichia coli. J BiolChem 2003, 278:30193-30198.

50. Mikulecky PJ, Kaw MK, Brescia CC, Takach JC, Sledjeski DD, Feig AL: Escherichia coli $\mathrm{Hfq}$ has distinct interaction surfaces for DsrA, rpoS and poly(A) RNAs. Nat Struct Mol Biol 2004, 11:1206-1214.

51. Guisbert E, Rhodius VA, Ahuja N, Witkin E, Gross CA: Hfq modulates the sigmaE-mediated envelope stress response and the sigma32-mediated cytoplasmic stress response in Escherichia coli. J Bacteriol 2007, 189:1963-1973.

52. Alekshun MN, Levy SB: The mar regulon: multiple resistance to antibiotics and other toxic chemicals. Trends Microbiol 1999, 7:410-413.

53. Kanai T, Takahashi K, Inoue H: Three distinct-type glutathione S-transferase from Escherichia coli important for defense against oxidative stress. J Biochem 2006, 140:703-711.

54. Bochner BR, Lee PC, Wilson SW, Cutler CW, Ames BN: AppppA and related adenylylated nucleotides are synthesized as a consequence of oxidation stress. Cell 1984, 37:225-232

55. Imlay JA: Pathways of oxidative damage. Annu Rev Microbiol 2003, 57:395-418.

56. Teufel R, Mascaraque V, Ismail W, Voss M, Perera J, Eisenreich W, Haehnel W, Fuchs G: Bacterial phenylalanine and phenylacetate catabolic pathway revealed. Proc Natl Acad Sci U S A 2010, 107:14390-14395.

57. Hussain H, Grove J, Griffiths L, Busby S, Cole J: A seven-gene operon essential for formate-dependent nitrite reduction to ammonia by enteric bacteria. Mol Microbiol 1994, 12:153-163.

58. Bitoun JP, Wu G, Ding H: Escherichia coli FtnA acts as an iron buffer for re-assembly of iron-sulfur clusters in response to hydrogen peroxide stress. Biometals 2008, 21:693-703.

59. Andrae U, Singh J, Ziegler-Skylakakis K: Pyruvate and related alpha-ketoacids protect mammalian cells in culture against hydrogen peroxide-induced cytotoxicity. Toxicol Lett 1985, 282:93-98.

60. Kovalenko TN, Ushakova GA, Osadchenko I, Skibo GG, Pierzynowski SG: The neuroprotective effect of 2-oxoglutarate in the experimental ischemia of hippocampus. J Physiol Pharmacol 2011, 62:239-246. 
61. Rensing C, Mitra B, Rosen BP: The zntA gene of Escherichia coli encodes a Zn(II)-translocating P-type ATPase. Proc Natl Acad Sci U S A 1997 94:14326-14331.

62. Ciavardelli D, Ammendola S, Ronci M, Consalvo A, Marzano V, Lipoma M, Sacchetta P, Federici G, Di Llio C, Battistoni A, Urbani A: Phenotypic profile linked to inhibition of the major $\mathrm{Zn}$ influx system in Salmonella enterica: proteomics and ionomics investigations. Mol Biosyst 2011, 7:608-619.

63. Chvapil M: New aspects in the biological role of zinc: a stabilizer of macromolecules and biological membranes. Life Sci 1973, 13:1041-1049.

64. Sugarman B: Zinc and infection. Clin Infect Dis 1983, 5:137-147.

65. Shankar AH, Prasad AS: Zinc and immune function: the biological basis of altered resistance to infection. Am J Clin Nutr 1998, 68:447S-463S.

66. Helbig K, Grosse C, Nies DH: Cadmium toxicity in glutathione mutants of Escherichia coli. J Bacteriol 2008, 190:5439-5454.

67. Morales EH, Calderón IL, Collao B, Gil F, Porwollik S, McClelland M, Saavedra CP. Hypochlorous acid and hydrogen peroxide-induced negative regulation of Salmonella enterica serovar Typhimurium ompW by the response regulator ArcA. BMC Microbiol 2012, 12:63.

68. Chasteen TG, Fuentes DE, Tantaleán JC, Vásquez CC: Tellurite: history, oxidative stress, and molecular mechanisms of resistance. FEMS Microbio/ Rev 2009, 33:820-832.

69. Makui H, Roig E, Cole ST, Helmann JD, Gros P, Celler MF: Identification of the Escherichia coli K-12 Nramp orthologue (MntH) as a selective divalent metal ion transporter. Mol Microbiol 2000, 35:1065-1078.

70. Baba T, Ara T, Hasegawa M, Takai Y, Okumura Y, Baba M, Datsenko KA, Tomita M, Wanner BL, Mori H: Construction of Escherichia coli K-12 in-frame, single-gene knockout mutants: the Keio collection. Mol Syst Biol 2006, [Online] Available at: http://onlinelibrary.wiley.com/doi/10.1038/ msb4100050/full. Accessed on 27 June 2014.

71. Yamamoto K, Ishihama A: Transcriptional response of Escherichia coli to external copper. Mol Microbiol 2005, 56:215-227.

72. Gentleman RC, Carey VJ, Bates DM, Bolstad B, Dettling M, Dudoit S, Ellis B, Gautier L, Ge Y, Gentry J, Hornik K, Hothom T, Huber W, Lacus S, Irizarry R, Leisch F, Li C, Maechler M, Rossini AJ, Sawitzki G, Smith C, Smyth G, Tiemey L, Yang JY, Zhang J: Bioconductor: open software development for computational biology and bioinformatics. Genome Biol 2004, 5:R80.

73. Ritchie ME, Silver J, Oshlack A, Holmes M, Diyagama D, Holloway A Smyth GK: A comparison of background correction methods for two-colour microarrays. Bioinformatics 2007, 23:2700-2707.

74. Smyth GK: Speed, TP Normalization of cDNA microarray data. Methods 2003, 31:265-273.

75. Keseler IM, Collado-Vides J, Santos-Zavaleta A, Peralta-Gil M, Gama-Castro S, Muñiz-Rascado L, Bonavides-Martinez C, Paley S, Krummenacker M, Altman T, Kaipa P, Spaulding A, Pacheco J, Latendresse M, Flucher C, Sarker M, Shearer AG, Mackie A, Paulsen I, Gunsalus RP, Karp PD: EcoCyc: a comprehensive database of Escherichia coli biology. Nucleic Acids Res 2011, 39:D583-D590.

76. Pfaffl MW: A new mathematical model for relative quantification in real-time RT-PCR. Nucleic Acids Res 2001, 29:e45.

77. Montes RA, Pradenas GA, Pérez-Donoso JM, Vásquez CC, Chasteen TG: The acute bacterial toxicity of the selenocyanate anion and the bioprocessing of selenium by bacterial cells. Environ Biotech 2012, 8:32-38

doi:10.1186/1471-2164-15-1099

Cite this article as: Monrás et al:: Microarray analysis of the Escherichia coli response to CdTe-GSH Quantum Dots: understanding the bacterial toxicity of semiconductor nanoparticles. BMC Genomics 2014 15:1099.

\section{Submit your next manuscript to BioMed Central and take full advantage of:}

- Convenient online submission

- Thorough peer review

- No space constraints or color figure charges

- Immediate publication on acceptance

- Inclusion in PubMed, CAS, Scopus and Google Scholar

- Research which is freely available for redistribution 